\title{
Spinal Cord Ischemia Secondary to Aortic Dissection: Case Report with Literature Review for Different Clinical Presentations, Risk Factors, Radiological Findings, Therapeutic Modalities, and Outcome
}

\author{
Hosna Elshony ${ }^{a} \quad$ Abdelrahman Idris $^{b} \quad$ Alaa Ahmed $^{c} \quad$ Murouj Almaghrabi $^{c}$ \\ Walaa Ahmed ${ }^{c}$ Shouq Fallatah ${ }^{d}$ \\ aDepartment of Neuropsychiatry, Faculty of Medicine, Menoufia University, Shebin El Kom, \\ Egypt; bepartment of Neurology/Internal medicine, Security Forces Hospital, Makkah, \\ Saudi Arabia; 'Faculty of Medicine, Umm Al-Qura University, Makkah, Saudi Arabia; ${ }^{\mathrm{d} F a c u l t y}$ \\ of Medicine, Taif University, Taif, Saudi Arabia
}

Keywords

Aortic dissection · Spinal cord ischemia

\begin{abstract}
Aortic dissection (AD) is a serious condition that causes transient or permanent neurological problems that include spinal cord ischemia $(\mathrm{SCl})$, which occurs when $\mathrm{AD}$ extends into the descending aorta resulting in insufficient perfusion of segmental arteries that supplies the spinal cord. We report a 64-year-old male, presented with severe back pain, asymmetrical paresthesia, and weakness of both limbs, more in the left lower limb with loss of pinprick, temperature, and fine touch sensation on the lower left lower limb below the level of T5 with preserved proprioception and vibration and urine hesitancy. Computed tomography showed AD, Stanford type A, and spinal magnetic resonance imaging (MRI) showed hyperintense owl's eye sign at T5. The patient was diagnosed as anterior spinal artery syndrome secondary to an AD and referred for aortic surgical repair with good functional outcome. In our review to cases of $\mathrm{SCl}$ due to $\mathrm{AD}$, it was more common in males above 55 years, pain only found in $47.8 \%$ of patients, with anterior cord syndrome on top of the clinical presentations, and hypertension is the most common risk factor. MRI spine showed thoracic location predominance. Surgical or endovascular repair especially for type $A$ and complicated type B should be considered to
\end{abstract}


avoid complications, and cerebrospinal fluid drainage is a very useful tool in reversing $\mathrm{SCl}$ specially if done early with favorable outcome. Only the old age is associated with increased risk of mortality. Early diagnosis and appropriate management are crucial for better outcome.

(C) 2021 The Author(s).

Published by S. Karger AG, Basel

\section{Introduction}

Spinal cord infarction is a rare condition with few reliable estimates of its incidence. According to the previous studies, it accounts for $1.2 \%$ of all strokes [1] and 5-8\% of all myelopathies [2]; however, recent studies have shown that myelopathy related to ischemic diseases accounts for $14-18 \%$ of patients with transverse myelitis, suggesting the underdiagnosis of SCI [3]. The age of onset ranges from the first decade to the tenth decade, with a median age between 50 and 70 years old [4]. SCI usually presents as anterior spinal artery syndrome or anterior spinal cord syndrome (ASCS) in up to $87.2 \%$ of the cases [5, 6]. SCI in territory of posterior spinal artery is very rare and involves posterior columns of the spinal cord. It presents with paresthesias and abolition of deep sensation below the level of the infarct. Occlusion of a central sulcal artery rarely produces small lesions in half of the spinal cord. This can present as an incomplete Brown-Séquard syndrome. Total transverse SCI involves both anterior and posterior spinal artery territory and may be misdiagnosed as transverse myelitis [7].

In one larger study of ASCI, 33\% of cases were attributed to atherosclerotic disease, $16 \%$ to aortic pathology, and $16 \%$ to degenerative spine disease [2]. Approximately, $1 \%$ of patients presenting with acute type A aortic dissection will have spinal cord stroke [8]. A case of thoracoabdominal aortic aneurysm, with or without associated dissection, is also associated with spinal cord ischemia [9]. Also a significant number of cases of spinal cord ischemia occur in the periprocedural setting with up to $45 \%$ of all reported cord infarctions that are iatrogenic [10].

In this paper, we report a case of anterior spinal cord ischemia caused by aortic artery dissection (AAD) with literature review for other similar cases, aiming to come out with certain criteria for patient at risk, common clinical presentations, imaging findings, different therapeutic modalities, and outcome, hoping to help in improving the diagnostic and therapeutic yield of such rare yet devastating cases.

\section{Case Presentation}

We report a case of 64-year-old male known to be diabetic, hypertensive, dyslipidemic, and heavy smoker complicated with chronic obstructive pulmonary disease. In March 2020, he was presented to ER in our hospital with sudden severe progressive excruciating tearing interscapular back pain, which was radiating over the thorax posteriorly and spreading into the sides down the spine of 1-day duration, and it was continuous and progressively worsening. The pain was soon followed with weakness of both lower limbs, more on the left side. He was unable to walk, with loss of sensation in the left lower limb and hesitancy of micturition. There was no history of trauma or other cardiac or neurological symptoms.

On examination, he was fully conscious, oriented to time, place, and person, with normal speech, memory, and cranial nerves. Regarding the upper limbs, motor, sensory examination, and coordination were all normal including deep tendon reflexes). In the lower limbs, tone

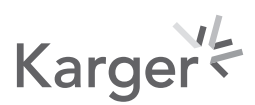


Fig. 1. CT axial view without contrast shows dilated ascending and descending aorta, and intramural thickening with wall calcification. CT, computed tomography.

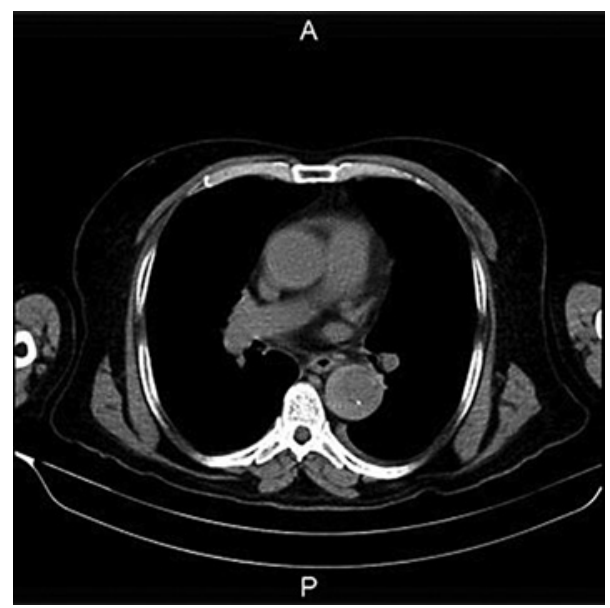

was normal and power was 2 over 5 in the left lower limp and 4 over 5 on the right on MRS scale, and deep tendon reflexes including knee and ankle jerks were brisker on the left side than on the right. Planter response was extensor on the left and equivocal on the right side. Vibration and position sensation were normal in both lower limbs with no sacral hypoesthesia. However, pinprick, temperature, and fine touch sensations were impaired in the whole left lower limb up to L1, and it was normal on the right side. Examination of the spine revealed no tenderness, deformities, or bruises. On the second day, after $48 \mathrm{~h}$ of symptom onset, the patient showed a partial improvement to grade $4 / 5$ on the left and 5/5 on the right side, but still sensory impairment was the same.

His blood pressure at admission was 177/92 mm Hg in both arms, and pulses in the upper limbs and carotids were normal but impaired in both lower limbs (femoral and popliteal). Cardiac examination revealed normal heart sound with regular rate and rhythm without any murmurs or gallops in auscultation. Respiratory and abdominal examinations were normal.

Regarding investigations, cardiac enzymes were done, including creatinine kinase (552 $\mathrm{U} / \mathrm{L})$ and troponin I $(0.073 \mathrm{Ng} / \mathrm{mL})$, and revealed an elevation, which is a suggestive of heart ischemic injury. ECG showed sinus rhythm/with diffuse deep $T$ wave inversion in all leads. In addition, the lipid profile was elevated, in which total cholesterol was $244.7 \mathrm{mg} / \mathrm{dL}$, cholesterol (HDL) was $58.10 \mathrm{mg} / \mathrm{dL}$, cholesterol (LDL) was $163.3 \mathrm{mg} / \mathrm{dL}$, and triglycerides were $187.90 \mathrm{mg} / \mathrm{dL}$. Routine CBC and chemistry were all normal. In addition, thyroid function profile, coagulation profile, hemoglobin $\mathrm{A} 1 \mathrm{C}$, prostate-specific antigen, autoimmune profile, electrolyte profile $(\mathrm{Na}+, \mathrm{K}+, \mathrm{Cl}-)$, and creatinine level were all done and revealed normal results.

A posterior-anterior and lateral chest X-ray revealed bilateral accentuated bronchovesicular markings and dilated unfolded aorta, unfolded knuckle with right-side tracheal shift. Computed tomography (CT) of the brain was done and revealed normal findings. CT of thorax demonstrated that an enlarged left ventricle with extensive intramural hematoma extends along the whole course of the aorta down to its bifurcation (ascending, arch, and descending). This represents an atypical type of aortic dissection (AD) of type A Stanford classification. The intramural hematoma is seen of high attenuation in the precontrast phase with the total filling of the lumen at the postcontrast phase (Fig. 1, 2). No obvious intimal flap as well as no evidence of contrast leak could be detected. The aortic arch measures about $4.3 \mathrm{~cm}$ with residual patent lumen $=2.2 \mathrm{~cm}$. In addition, the descending thoracic aorta measures about $4 \times 3.6 \mathrm{~cm}$ with residual patent lumen $=2.4 \times 1.8 \mathrm{~cm}$. An echocardiogram showed 

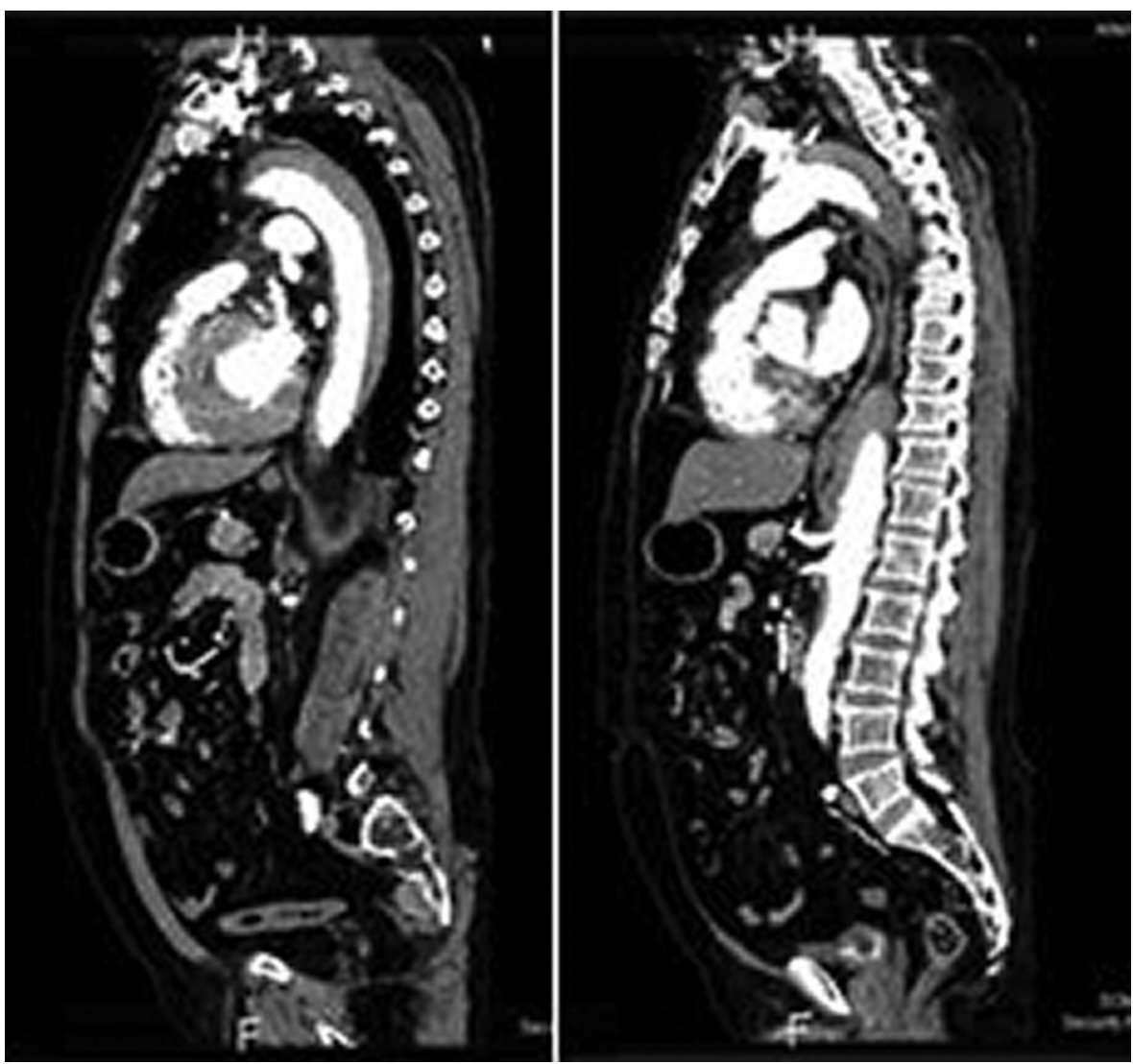

Fig. 2. CT sagittal view with contrast shows filling defect consisting of thrombus extending from the ascending to descending aorta. CT, computed tomography.

moderate-to-severe left ventricular systolic dysfunction $(\mathrm{EF}<30 \%)$, grade 1 diastolic dysfunction, multiwall motion abnormality, and mild dilatation in aortic root, and the rest of cardiac valves were normal.

Magnetic resonance imaging (MRI) of the dorsal spine revealed a small focal linear area of the abnormal intramedullary signal. It was noticed opposite to the T5 vertebral body, exhibiting a bright signal in T2-weighted image, short tau inversion recovery, and the isointense signal in T1-weighted image (Fig. 3). It mainly affects the ventral paramedian aspects of the cord, with subtle cord expansion. It measures about $2 \mathrm{~cm}$ in maximum craniocaudal length. No significant contrast enhancement could be detected (Fig. 4). MRI of the lumbar spine showed multiple degenerative features, L4 and L5 disc bulge and facet arthropathy, and L5 bilateral pars break. No evidence of cauda equina compression noticed.

The neurological findings were consistent with acute asymmetric anterior cord syndrome, rather than Brown-Séquard syndrome nor complete anterior cord syndrome. The following conditions were considered: spinal cord infarction, myelitis, sudden compression from secondary versus deposits, hematomyelia, and acute demyelination. The presence of significance and continuous interscapular back pain was in the presence of normal strangle, and suggestion of AD supports the diagnosis of acute vascular lesion of the spinal cord.

During the hospital course, the patient was on paracetamol and naproxen. In addition, he was managed with oral amlodipine and this resulted in reduction of blood pressure. The patient referred to a cardiac surgeon where a Bentall surgery was performed for him. The 

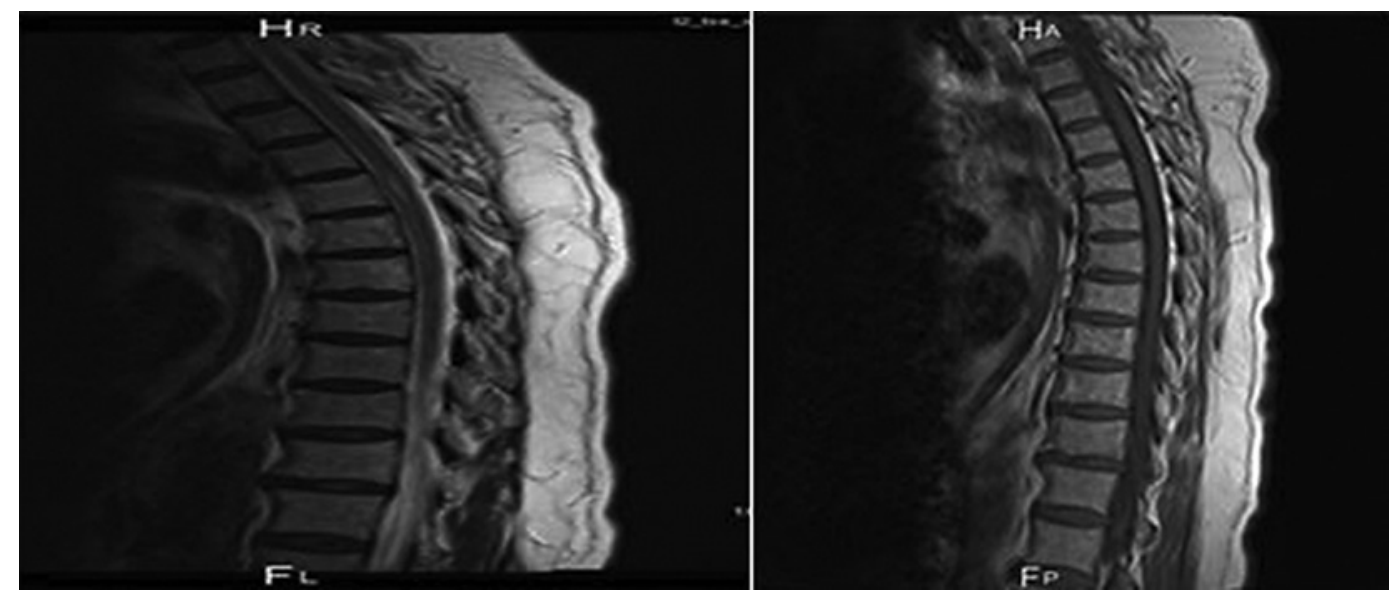

Fig. 3. a MRI T2 sagittal view show small focal linear intramedullary hypodensity at the level of T5. b MRI T1 sagittal view shows iso-intense spinal cord. MRI, magnetic resonance imaging.

Fig. 4. MRI sagittal view postenhanced was unremarkable. MRI, magnetic resonance imaging.

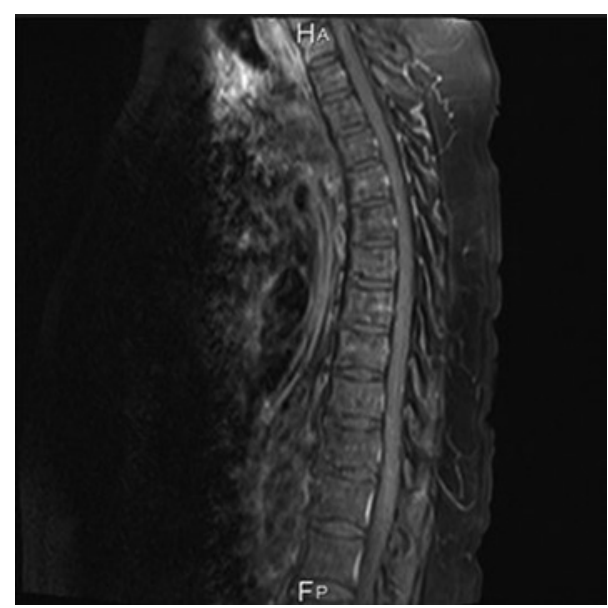

composite graft replacement was done regarding ascending aorta, arch, and coronary artery. Postsurgery outcomes include significant improvement of the pain and remarkable recovery, and no postoperative complications were detected. After the surgery, the patient undergone physiotherapy and started to walk independently 1 week after surgery.

\section{Discussion}

Transient or permanent neurological symptoms at onset of AD are often dramatic and may mask the underlying condition especially in pain-free dissection (5-15\%). They are usually caused by either dissection/occlusion of one or more aortic side branches supplying brain, spinal cord, or peripheral nerves or hypoperfusion. They usually appear at or shortly after the onset of dissection with rapid improvement resulting from transient arterial occlusion at the moment of propagation of the dissection $[8,11]$. Their frequency varies between 17 and 40\%, including persistent or transient ischemic stroke (in 2.6-32\%), ischemic neuropathy (in 4.2-24\%), and less commonly spinal cord ischemia (in 1-8.9\%), as well as hypoxic encephalopathy and syncope in some patients $[10,12-16]$.

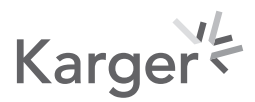


SCI on the basis of AD is a rare syndrome and more common with distal ADs. In a study by Sandhu et al. [17], from 1999 to 2014, they managed 978 AADs, comprising 482 with AD type A (88\% DeBakey type I and $12 \%$ type II) and 496 with AD type B (96.4\% type III and $3.6 \%$ abdominal). Neurological symptoms were present in 178 (18.2\%), of which 52 (29.2\%) presented with SCI. Isolated SCI (paraplegia/paraparesis in the absence of other malperfusion symptoms) was present in 28 AADs (2.9\%). All SCIs occurred in DeBakey type I or III ADs. Of these 52 patients, 10 were females and 42 males. Chest pain was present in 40 patients, HTN in 22 patients, smoking in 16 patients, and genetic syndrome in 5 patients. Twenty-four patients undergone open surgery and 3 patients undergone endovascular surgery. Ten patients died, partial recovery in 5 patients, and complete recovery in 26 patients.

We conducted a systematic meta-synthesis literature review for cases of SCI caused by AD through searching the PubMed till April 2021. We found another 66 cases to fulfill our search criteria plus our case. Analyzing data from those 67 cases, we tried to explore the patient criteria, common presentations, risk factors, radiological findings, therapeutic interventions, and outcome in such cases (Table 1) [18-73].

Mean age and gender distribution in AD patients with neurological involvement do not differ from those without neurological involvement $[11,14]$. In our 67 collected cases, 21/63 $(33.3 \%)$ were females and $42 / 63(66.6 \%)$ were males, with 4 cases sex not available (Table 2 ). So, the number of males doubles the number of females. As for age, it was ranged from 40 to 92 with $68.5 \%$ above 55 years, with a mean age of 60 and only 1 case aged 24 years (Table 2). This comes in agreement with Mayo Clinic who reported that male sex and age from 60 to 80 years old consider being one of the potential risks of $\mathrm{AD}$ [74].

Owing to the ischemic pathology, the onset of symptoms is usually acute and this was the case in all 67 cases. Pain is the most common presenting symptom of AD and could be the sign that directs the physician attention to think about $\mathrm{AD}$ as etiology for a case of paraplegia, with $95 \%$ of patients reported any pain, usually midline, in front and back of trunk depending on the location of dissection, localized to chest in 73\%, anterior >posterior (61 vs. $36 \%$ ), back in $53 \%$, and abdomen in $30 \%$ of patients, which may extend down the back to the hips and legs in cases where dissection process extends distally [112]. Remarkably, chest pain is not an obligatory symptom of $\mathrm{AD}$, and the frequency of pain-free dissections ranges between 5 and $15 \%[11,12,75,112]$ especially in patients with neurological sequelae $[11,19,20,75-82]$. In a study by Gaul et al. [8], only two-thirds of the patients with neurological symptoms at onset of dissection complained of pain, whereas most patients without neurological symptoms (94.4\%) experienced initial pain. Approximately half of all patients who did not report pain showed neurological symptoms only [11], which make the diagnosis very challenging. In our review, pain was present in 32/67 (47.8\%), which is much less expected in usual cases of AD (95\%). Most patients experienced severe chest pain (18 cases [34.4\%]), extended to the back in 2 cases, and localized to back only in another 11 (40.6\%) cases (Table 3). The pain was usually severe, continuous, and excruciating.

Clinical manifestations of SCI comprise complete spinal cord infarction as well as ASCS, Brown-Séquard syndrome, progressive myelopathy, or transient spinal cord ischemia [79, 81, 83, 84]. Pure posterior spinal artery (PSA) infarction in SCI is relatively rare based on previous case studies [85-87]. In a recent study that comprised of the largest series of PSA infarctions (133 patients with SCI), 15 (11\%) patients had a spontaneous PSA infarction [88]. This figure suggests that the diagnosis of PSA infarction might be underrecognized in SCI [86]. In our review, the presentation was anterior cord syndrome in 31/67 (46.2\%) followed by pure motor in 26/67 (38.8\%), then complete cord syndrome in 5/67 (7.4\%), pure sensory in $2 / 60$ (2.9\%), Cauda equine syndrome in 2/67 (2.9\%), and Brown-Séquard syndrome in 1/67 (1.49\%). None of them had isolated posterior cord syndrome (Table 3).

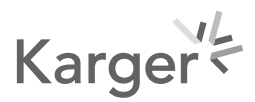


Case Reports in

Neurology
Case Rep Neurol 2021;13:634-655 DOI: $10.1159 / 000518197$

(c) 2021 The Author(s)
www.karger.com/crn

Elshony et al.: SCI Secondary to Aortic Dissection: Case Report with Literature Review

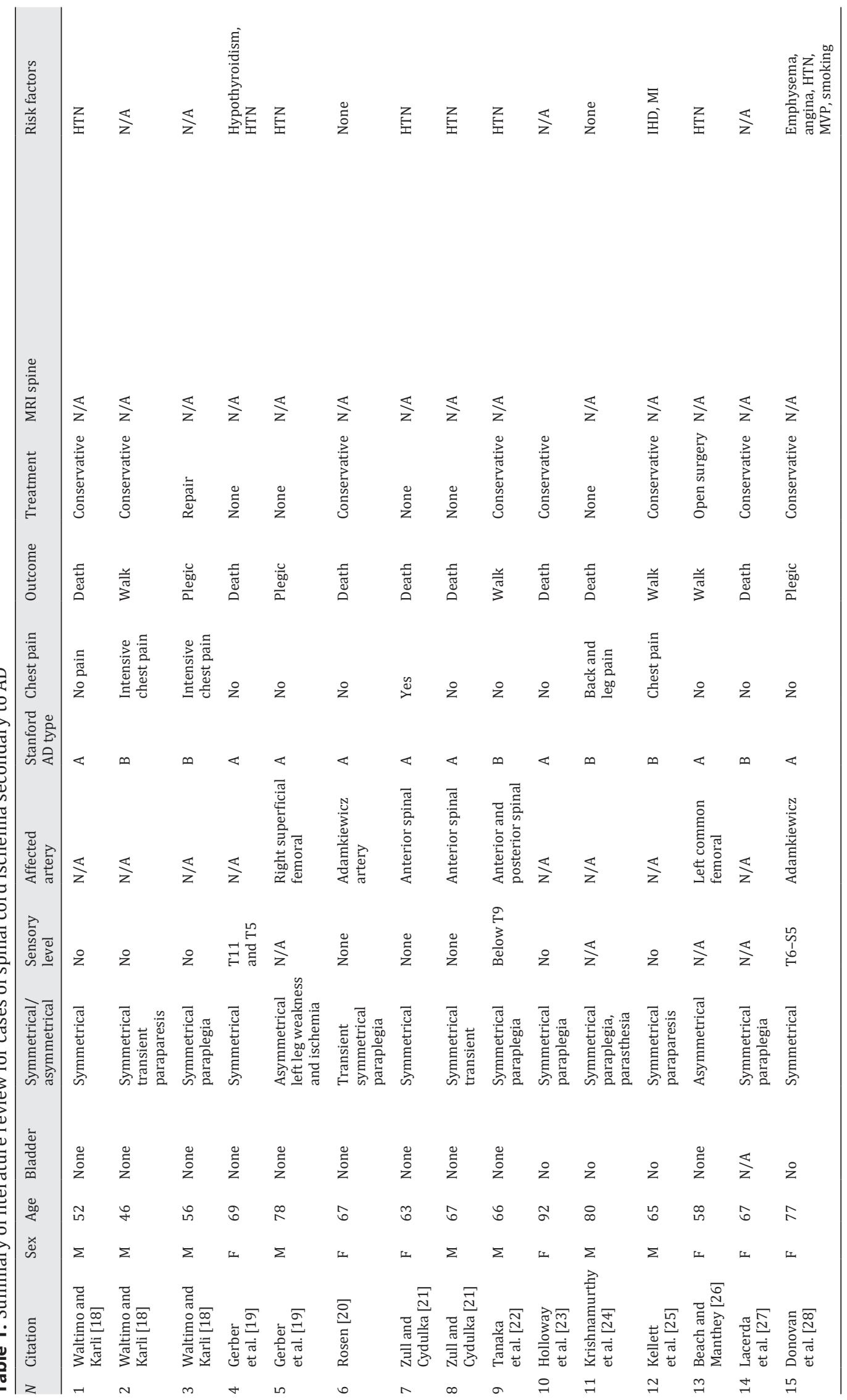


Case Reports in

Neurology
Case Rep Neurol 2021;13:634-655

DOI: 10.1159/000518197

(c) 2021 The Author(s).
www.karger.com/crn

Elshony et al.: SCI Secondary to Aortic Dissection: Case Report with Literature Review

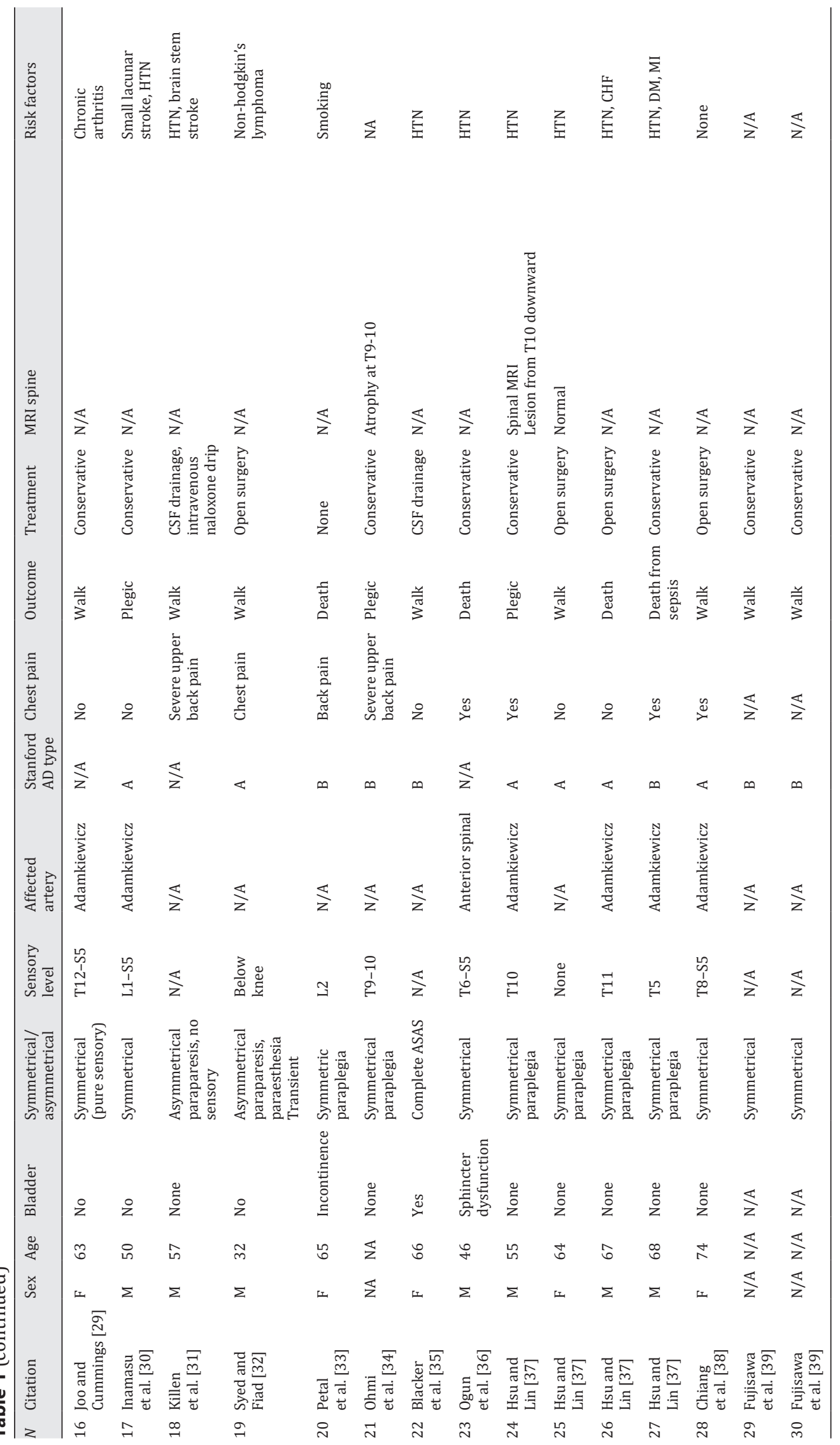




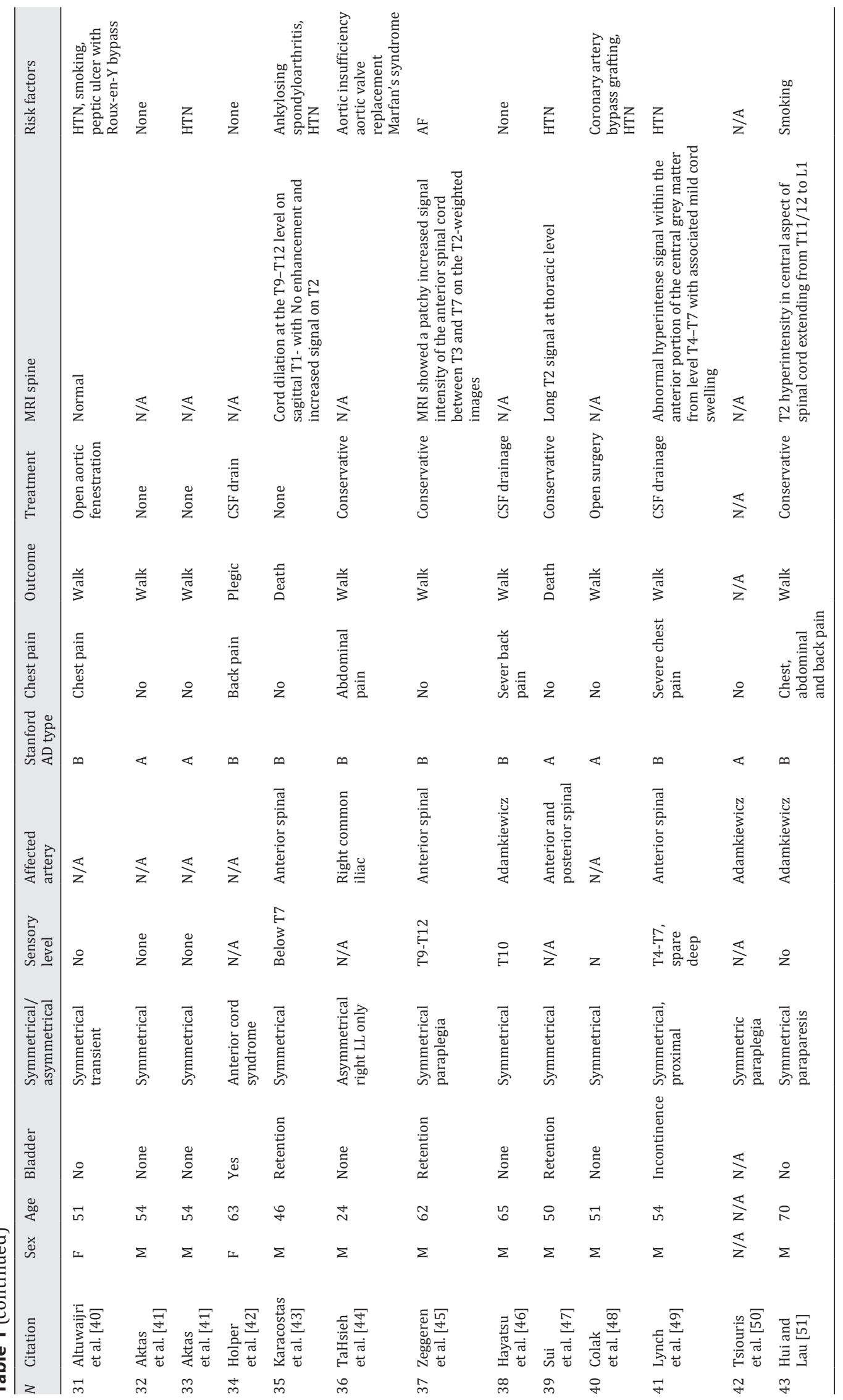


Case Reports in

Neurology

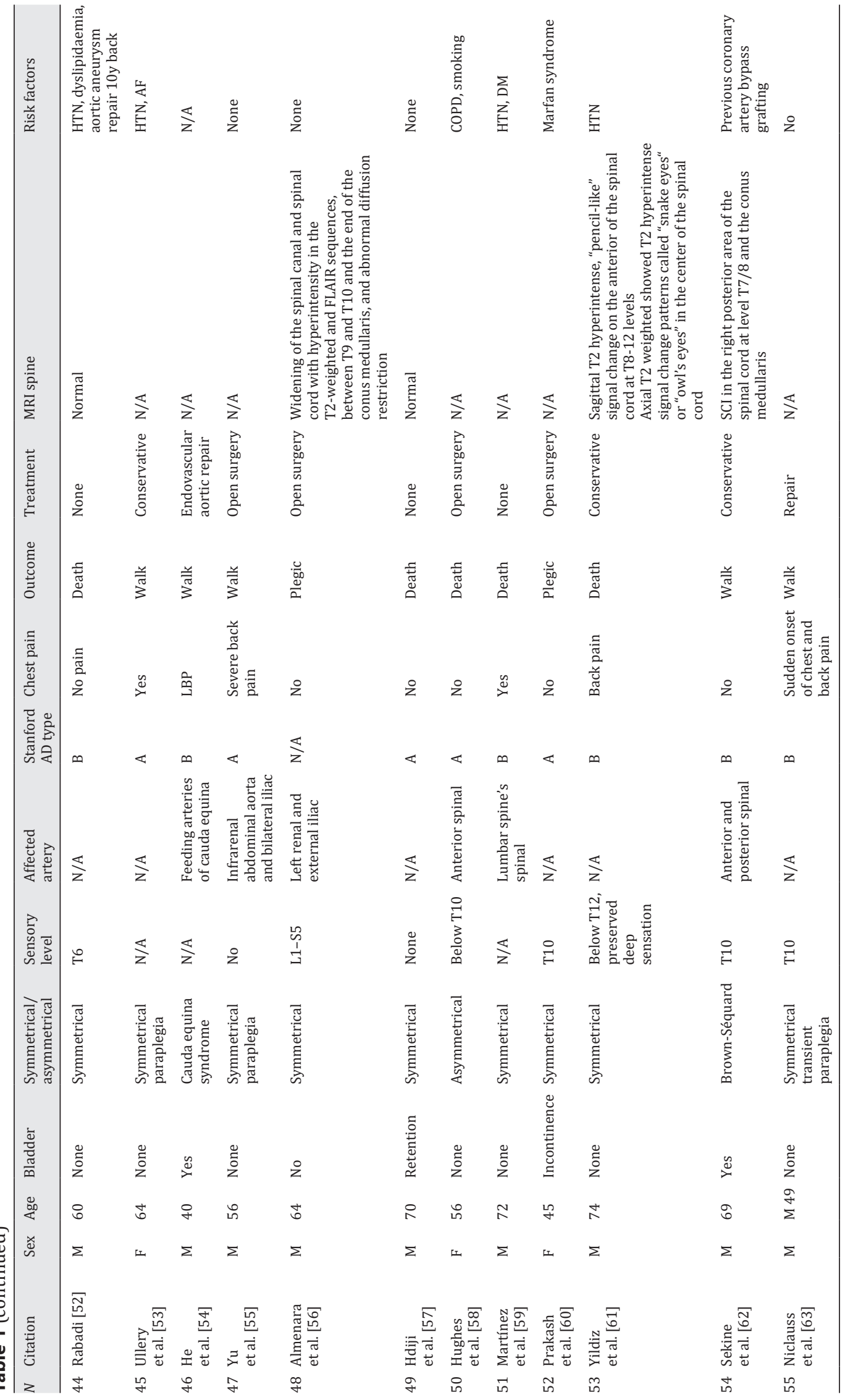


Case Reports in

Neurology
Case Rep Neurol 2021;13:634-655 DOI: 10.1159/000518197 www.karger.com/crn
w

Elshony et al.: SCI Secondary to Aortic Dissection: Case Report with Literature Review

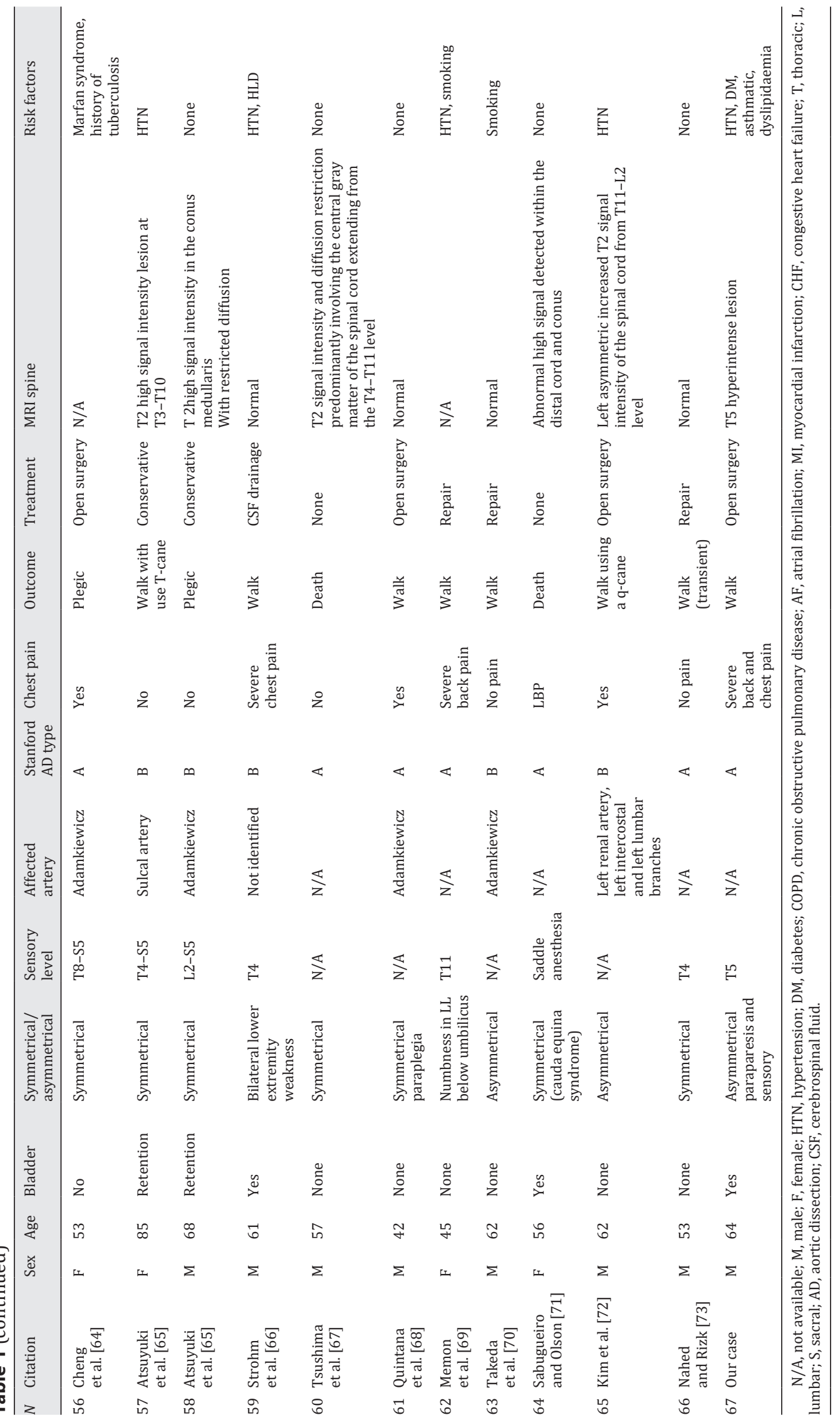


Case Reports in Neurology

Table 2. Sociodemographic criteria among the studied patients

\begin{tabular}{l|l}
\hline Case Rep Neurol 2021;13:634-655 \\
\hline DOI: 10.1159/000518197 & $\begin{array}{l}\text { ○ 2021 The Author(s). Published by S. Karger AG, Basel } \\
\text { www.karger.com/crn }\end{array}$ \\
\hline
\end{tabular}

\begin{tabular}{lc}
\hline Parameters & $\begin{array}{l}\text { The studied patients } \\
N=67\end{array}$ \\
\hline Age, years & \\
Mean \pm SD & $60.06 \pm 11.60$ \\
Range & $24-92$ \\
Sex, $n(\%)$ & \\
N/A & $4(6.0)$ \\
Male & $42(62.7)$ \\
Female & $21(31.3)$ \\
Risk factors, $n$ (\%) & \\
HTN & $32(47.8)$ \\
Smoking & $7(10.4)$ \\
DM & $3(4.5)$ \\
Cardiovascular (MI, angina, stroke, & $12(17.9)$ \\
AF, CHF, MVP, CABG) & \\
Hypothyroidism & $1(1.5)$ \\
Respiratory (asthma, COPD) & $4(6.0)$ \\
Arthritis & $2(3.0)$ \\
Marfan syndrome & $2(3.0)$ \\
Non-Hodgkin's lymphoma & $1(1.5)$ \\
&
\end{tabular}

N/A, not available; MI, myocardial infarction; $\mathrm{CHF}$, congestive heart failure; AF, atrial fibrillation; MVP, mitral valve prolapse; CABG, coronary artery bypass graft; COPD, chronic obstructive pulmonary disease; HTN, hypertension.

The symptoms are almost bilateral symmetrical since both halves of the anterior spinal cord are supplied from one anterior midline spinal cord. However, the ASCS with unilateral symptomatology has rarely been reported; this may be due to occlusion of unilateral sulcal arteries or collateralization from one posterior spinal artery [89] as it could be the explanation to our case with asymmetrical incomplete paraparesis with loss of sensation on left LL till L1 and also in 10 other cases from the literature totally 11/67 (16.49\%), being strictly unilateral in only 1 case.

As we mentioned before, the symptoms could be permanent or transient. Seven out of sixty-seven cases $(10.4 \%)$ had transient symptoms with spontaneous recovery in 4 cases, and conditioned recovery after intervention in 3 cases ( 1 after endovascular fenestration and 2 after CSF drainage).

If the location of the infarction involves the lateral horns within levels T1-L2 of the spinal cord, it will cause autonomic dysfunction, including neurogenic bowel/bladder, which requires bladder catheterization [90,91]. Bladder symptoms in the form of hesitancy, retention, or incontinence were found in 17/63 (26.9\%) patients, with the level between T3 and L1 (Table 3).

The most common risk factor for AD is poorly controlled hypertension (HTN) (65-75\% risk with a history of HTN) [74]. Other risk factors include age, male sex, smoking, preexisting aortic diseases or aortic valve disease, family history of aortic diseases, history of cardiac surgery, direct blunt trauma, and the use of intravenous drugs (such as cocaine or amphetamines) [92]. In our review, HTN was on the top of the vascular risk factors being present in $32 / 62$ (51.6\%) cases. Out of 62 patients, 7 patients (11.29\%) were smokers, 3 with DM, 2 with 
Case Reports in

Neurology

Table 3. Clinical data among the studied patients

The Author(s). Published by S. Karger AG, Base www.karger.com/crn

Elshony et al.: SCI Secondary to Aortic Dissection: Case Report with Literature Review

\begin{tabular}{|c|c|}
\hline Parameters & The studied patients $(N=67)$ \\
\hline \multicolumn{2}{|l|}{ Bladder } \\
\hline $\mathrm{N} / \mathrm{A}$ & 4 \\
\hline Yes & 17 \\
\hline No & 46 \\
\hline \multicolumn{2}{|l|}{ Symmetry } \\
\hline Symmetrical & 56 \\
\hline Asymmetrical & 11 \\
\hline \multicolumn{2}{|l|}{ Affected artery } \\
\hline N/A & 35 \\
\hline Adamkiewicz & 15 \\
\hline Anterior spinal & 7 \\
\hline Anterior and posterior spinal & 3 \\
\hline Femoral arteries & 2 \\
\hline Iliac arteries & 1 \\
\hline Sulcal arteries & 1 \\
\hline Feeding arteries of cauda equine & 1 \\
\hline Renal and iliac arteries & 2 \\
\hline \multicolumn{2}{|l|}{ Stanford AD type } \\
\hline N/A & 4 \\
\hline A & 32 \\
\hline $\mathrm{B}$ & 31 \\
\hline \multicolumn{2}{|l|}{ Pain, $n(\%)$} \\
\hline Yes & $32(47.8)$ \\
\hline No & $35(52.2)$ \\
\hline Pain location & $N=32$ \\
\hline Chest & 18 \\
\hline Back & 11 \\
\hline Chest and back & 2 \\
\hline Chest, back, and abdomen & 1 \\
\hline \multicolumn{2}{|l|}{ Duration, $n(\%)$} \\
\hline Transient & $7(10.4)$ \\
\hline Permanent & $60(89.6)$ \\
\hline \multicolumn{2}{|l|}{ MRI findings, $n(\%)$} \\
\hline N/A & 43 \\
\hline Normal & 8 \\
\hline Thoracic & 10 \\
\hline Conus & 2 \\
\hline Thoracic and conus & 2 \\
\hline Thoracolumber & 1 \\
\hline Thoracolumber and conus & 1 \\
\hline \multicolumn{2}{|l|}{ Treatment, $n(\%)$} \\
\hline N/A & 1 \\
\hline No treatment & 14 \\
\hline Conservative & 25 \\
\hline CSF drainage & 6 \\
\hline Endovascular & 2 \\
\hline Open surgery & 19 \\
\hline \multicolumn{2}{|l|}{ Outcome, $n(\%)$} \\
\hline N/A & 1 \\
\hline Walk & $34(52.2)$ \\
\hline Plegic & $11(16.4)$ \\
\hline Death & $21(31.3)$ \\
\hline
\end{tabular}

N/A, not available; CSF, cerebrospinal fluid; MRI, magnetic resonance imaging; $\mathrm{AD}$, aortic dissection. 
Marfan syndrome (3.2\%), 2 had previous stroke, 2 had previous history of angina, 2 had coronary artery grafting, 2 with asthma, 1 with mitral valve prolapse (1.6\%), 1 with emphysema, 1 with chronic obstructive pulmonary disease, 1 with atrial fibrillation, 1 with congestive heart failure, 1 with hypothyroid, and 1 with non-Hodgkin's lymphoma (Table 2).

Diagnosis of spinal cord ischemia is done by taking a detailed history, performing physical examination, and also neuroimaging studies. MRI of the spine is usually done to confirm the diagnosis, although, in the first $24 \mathrm{~h}$, the results may appear negative. Hyperintensity in the anterior horns in the T2-weighted image is the hallmark observation. Anterior spinal artery syndrome findings indicate a thin "pencil-like" hyperintense region that spreads vertically affecting several spinal levels in the sagittal view, 2 bright dots at each anterior horn on the axial view identified as owl's eyes, T1-weighted hypointensity at the injured area, spinal cord expansion at the injury site due to early signs of inflammation/edema (diffusion-weighted images that help distinguish between ischemia and inflammation), and signs of vertebral body infarction that are not always present are other results indicating a spinal cord infarction $[89,93,94]$. In our review, out of the 24 cases undergone MRI spine, 8 cases were normal and the other 16 cases showed hyperintense T2 lesions in different locations, 1 delayed MRI shows cord atrophy, with the typical owl eye sign found only in 3 cases.

In a study by Hsu et al. [91], comparing SCI in patients with to those without vessel dissection, it was found that in the vessel dissection group, patients frequently had lesions involving the upper cervical (C1-C4) and lower thoracic (T10-T12) vertebral body levels. In contrast, patients without vessel dissection more frequently had lesions distributed in the cervical regions (C5-T7) than in the thoracolumbar regions, with more posterior involvement [92]. In our review, out of the 16 cases with positive MRI, the level was as high as T3 and as low as conus medullaris with no cases with cervical affection, being at a thoracic level in $10 / 24(41.6 \%)$ cases, conus in $2 / 24(8.3 \%)$ cases, thoracic and conus in $2 / 24(8.3 \%)$ cases, thoracolumbar in $1 / 24(4.16 \%)$ case, and thoracic, lumbar, and conus in $1 / 24(4.16 \%)$ case (Table 3).

Spinal cord involvement in patients with AD could be secondary to obstruction of the intercostal and lumbar arteries, the Adamkiewicz artery (arteria radicularis magna), or the thoracic radicular arteries. Most frequently, the middle thoracic spinal cord, the watershed zone between the territories of the artery of Adamkiewicz, and the thoracic radicular artery are affected [83]. Among the 32 cases with well-defined occluded artery, 15/32 (46.8\%) had Adamkiewicz artery occlusion, followed by $7 / 32$ (21.8\%) with anterior spinal artery, 3/32 $(9.3 \%)$ with combined anterior and posterior spinal artery occlusion, $2 / 32(6.25 \%)$ with left renal left renal and external iliac arteries occlusion, and another 2 cases with right brachiocephalic and right iliac arteries. Each of sulcal artery, right superficial femoral artery, left common femoral artery, right common iliac artery, lumbar spine's spinal arteries, left renal, external iliac arteries, and bilateral iliac arteries was found in one case and one more case with occlusion of feeding arteries to cauda equina (Table 3).

For confirmation of the diagnosis, patients often require more than one noninvasive imaging study to characterize AD, with CT used in $61 \%$ of cases, echocardiography in $33 \%$, aortography in 4\%, and MRI in only 2\% [74]. Imaging helps in diagnosis and classification of the AD in order to decide best the therapeutic plan. Two classifications are most commonly used for AD. The DeBakey system is classified into 3 types (types I, II, and III) according to the site of the first entry of dissection [95]. Type I has the first entry in the ascending aorta and propagates distally to the descending aorta. Type II has the first entry in the ascending aorta and does not propagate to the aortic arch. Type III has the first entry in the descending aorta and propagates distally above (type IIIa) or below (type IIIb) the diaphragm. The Stanford system is classified into 2 types (types A and B) based on the involvement of the ascending aorta [96]. Type A includes dissection in the ascending aorta regardless of the

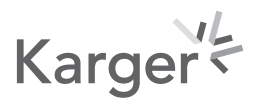


site of first entry. Type B does not include dissection in the ascending aorta. The usual incidence of different types of AD in a previous study was 37 (71.2\%) Stanford type A and 15 (28.8\%) type B [97]. In our review, the type of AD was identified in 63 cases; it was type $\mathrm{A}$ in $32 / 63(50.7 \%)$ cases and type B in 31/63 (49.2\%) cases with almost equal incidence (Table 3).

Regardless of whether acute AD is type A or B, medical therapy to control pain and HTN is essential in all patients. Beta blockers have the desired effect of reducing blood pressure and heart rate to the normal range [98]. These medications also protect the myocardium against ischemia. Otherwise, vasodilators such as calcium channel blockers (nicardipine or diltiazem) or nitroglycerin are useful in reducing HTN in an emergent situation. Multiple synergistic medications may be necessary for adequate hemodynamic control [99]. General guidelines stipulate a target systolic blood pressure of 100-120 mm Hg (except in patients presenting with paraplegia, where a systolic range of $120-130$ is generally employed) and a heart rate of 60-80 beats per minute [99, 100].

In patients with type A AD, surgical treatment is the gold standard; mortality is $50 \%$ within the first $48 \mathrm{~h}$ if surgery is not performed [101]. However, with type B AD, medical therapy including analgesia, antihypertensive drugs, and bed rest is performed. However, complicated type $\mathrm{B} A \mathrm{D}$, such as descending aortic rupture, uncontrolled pain, and malperfusion of the aortic branch or lower extremities, is an indication for urgent surgery [101]. More recently, thoracic endovascular aortic repair has become an alternative technique to treat complicated type B AD [102].

Lumbar cerebrospinal fluid (CSF) drainage helps prevent spinal cord injury for patients undergoing open or endoscopic thoracic or thoracoabdominal aortic aneurysm and thoracic endovascular aortic repair surgery $[103,104]$. When combined with augmentation of the systemic blood pressure, CSF drainage reduces the risk of SCI by increasing the afferent spinal cord blood supply and perfusion pressure by creating a low ambient pressure in the subarachnoid space that surrounds the spinal cord [105], with up to $80 \%$ reduction in the relative risk of postoperative deficits in cases of SCI [106-108]. Combinations of lumbar drain and intrathecal papaverine have also been successful in reducing the severity of neurological injury. Prompt detection of spinal cord ischemia by neurological examination and imaging, combined with interventions that increase cord perfusion, is crucial in effectively treating or reversing acute paraplegia or paraparesis and may even reverse cases of delayed onset paraplegia [109].

In our review, 19 patients undergone open surgical repair (12 with type $A, 4$ with type $B$, 1 on unknown type of AD), with good recovery in $13 / 19$ (68.4\%), residual plegia in $4 / 19$ (21\%) patients, and death in $2 / 19(10.5 \%)$ patients. Only 2 patient undergone endovascular repair with AD type B with favorable outcome in both cases. Six patients undergone CSF drainage; most of them are AD type B, with marked instant recovery in 5/6 (83.3\%) patients, but only 1 left with marked residual due to delayed procedure. Twenty-five patients received conservative medical treatment and 3 patients of unknown management and 12 patients received no treatment due to death (Table 4).

The overall spinal cord infarction mortality rate is estimated to be between 9 and $23 \%$ $[110,111]$. Most deaths occurred early after the SCI. In a study by Robertson et al. [10], older age, severe neurological impairment, and peripheral vascular disease were independently associated with increased mortality. In our review, death occurs in 21/67 (31.3\%) patients, $12 / 21(57.14 \%)$ of defined dissection type were A and 8/21 (38\%) were B, 1 of them died of sepsis, 1 of the unidentified type of AD. Older age was the only significant risk factor for mortality (Table 4).

The degree of functional motor and sensory dysfunction of survivors will vary. In a study by Robertson et al. [10] on long-term outcome in 115 SCI patients, among survivors, 37 (42\%)

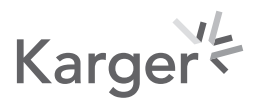


Table 4. Outcome of the patients in relation to sociodemographic criteria of the patients

\begin{tabular}{|c|c|c|c|c|}
\hline \multirow[t]{2}{*}{ Parameters } & \multicolumn{3}{|c|}{$\begin{array}{l}\text { The studied patients } \\
N=67\end{array}$} & \multirow[t]{2}{*}{$p$ value } \\
\hline & $\begin{array}{l}\text { walk } \\
N=34\end{array}$ & $\begin{array}{l}\text { plegic } \\
N=11\end{array}$ & $\begin{array}{l}\text { death } \\
N=21\end{array}$ & \\
\hline Age, years & & & & $0.63^{1}$ \\
\hline Mean \pm SD & $57.46 \pm 11.78$ & $60.82 \pm 10.53$ & $64.0 \pm 11.18$ & $0.045^{2}$ \\
\hline Range & $24-85$ & $45-78$ & $46-92$ & $0.37^{3}$ \\
\hline \multicolumn{5}{|l|}{ Sex, $n(\%)$} \\
\hline N/A & $2(8.6)$ & $1(9.1)$ & $0(0.0)$ & $0.78^{1}$ \\
\hline Male & $23(65.7)$ & $6(54.5)$ & $13(61.9)$ & $0.29^{2}$ \\
\hline Female & $9(25.7)$ & $4(36.4)$ & 8 (38.1) & $0.37^{3}$ \\
\hline \multicolumn{5}{|l|}{ Risk factors, $n(\%)$} \\
\hline Smoking & $4(11.7)$ & $1(9.1)$ & $2(9.5)$ & 0.96 \\
\hline HTN & $16(47)$ & $4(36.4)$ & $12(57.1)$ & 0.50 \\
\hline DM & $1(2.9)$ & $0(0.0)$ & $2(9.5)$ & 0.37 \\
\hline Cardiovascular & 7 (20.58) & $1(9.1)$ & $4(19.0)$ & 0.70 \\
\hline Hypothyroidism & $0(0.0)$ & $0(0.0)$ & $1(4.8)$ & 0.33 \\
\hline Respiratory & $1(2.9)$ & $2(18.2)$ & $1(4.8)$ & 0.17 \\
\hline Arthritis & $1(2.9)$ & $0(0.0)$ & $1(4.8)$ & 0.75 \\
\hline Marfan syndrome & $0(0.0)$ & $2(18.2)$ & $0(0.0)$ & 0.005 \\
\hline Non-Hodgkin's lymphoma & $1(2.9)$ & $0(0.0)$ & $0(0.0)$ & 0.63 \\
\hline
\end{tabular}

were using a wheelchair, 23 (26\%) were using a gait aid (cane or walker), and 29 (33\%) walked unaided. The results from univariate analysis suggested that severe impairment on initial examination, absence of Babinski sign, presence of sensory level, longitudinally extensive MRI lesions, and MRI lesions with the highest level in the thoracic region were associated with wheelchair and catheter use at a final follow-up. Age, gender, and comorbidities were not associated with functional outcome. But when it was adjusted for time to last followup using multivariate logistic regression, severity of impairment was the only variable associated with requiring wheelchair. In a study by Nedeltchev et al. [2], 41\% had regained full walking ability, $30 \%$ were able to walk with aids, $20 \%$ were wheelchair bound, and $9 \%$ had died. Severe initial impairment and female sex were independent predictors of unfavorable outcome.

In our review, outcome was good with almost complete recovery in 34/67 (50.7\%), while $11 / 67$ (20\%) patients ended in wheel chair after prolonged rehabilitation. Tables 4 and 5 demonstrate the outcome in relation to patient sociodemographic criteria, clinical presentation, radiological findings, and therapeutic modality. Age was not an indicator of bad prognosis in our cases, but the initial degree of disability and the lack of early improvement were associated with bad motor outcome. Age, gender, and comorbidities were not associated with functional outcome, but it was noticed that the 2 cases of Marfan syndrome ended up being plegic. There was no association between outcome and radiological findings or location of the lesion. Early diagnosis and appropriate treatment can improve the functional outcome with 
Table 5. Outcome of the cases in relation to clinical presentation, radiological findings and therapeutic modality

\begin{tabular}{|c|c|c|c|c|}
\hline \multirow[t]{2}{*}{ Parameters } & \multicolumn{3}{|c|}{$\begin{array}{l}\text { The studied patients } \\
N=67\end{array}$} & \multirow[t]{2}{*}{$p$ value } \\
\hline & $\begin{array}{l}\text { walk } \\
N=34\end{array}$ & $\begin{array}{l}\text { plegic } \\
N=11\end{array}$ & $\begin{array}{l}\text { death } \\
N=21\end{array}$ & \\
\hline $\begin{array}{l}\text { Bladder, } n(\%) \\
\text { N/A } \\
\text { Yes } \\
\text { No }\end{array}$ & $\begin{array}{c}2(5.88) \\
8(23.52) \\
24(70.58)\end{array}$ & $\begin{array}{l}0(0.0) \\
3(27.3) \\
8(72.7)\end{array}$ & $\begin{aligned} 1 & (9.5) \\
6 & (23.8) \\
14 & (66.7)\end{aligned}$ & 0.89 \\
\hline $\begin{array}{l}\text { Symmetry, } n(\%) \\
\text { Symmetrical } \\
\text { Asymmetrical }\end{array}$ & $\begin{array}{r}25(73.5) \\
9(26.5)\end{array}$ & $\begin{array}{c}10(90.9) \\
1(9.1)\end{array}$ & $\begin{array}{c}20(95.2) \\
1(4.8)\end{array}$ & 0.09 \\
\hline $\begin{array}{l}\text { Affected artery, } n(\%) \\
\text { N/A } \\
\text { Anterior spinal } \\
\text { Adamkiewicz } \\
\text { Anterior and posterior spinal } \\
\text { Femoral arteries } \\
\text { Iliac arteries } \\
\text { Sulcal arteries } \\
\text { Feeding arteries of cauda equine } \\
\text { Renal and iliac arteries }\end{array}$ & $\begin{aligned} 19 & (55.8) \\
2 & (5.8) \\
6 & (17.6) \\
2 & (5.8) \\
1 & (2.9) \\
1 & (2.9) \\
1 & (2.9) \\
1 & (2.9) \\
1 & (2.9)\end{aligned}$ & $\begin{array}{l}4(36.4) \\
0(0.0) \\
5(45.5) \\
0(0.0) \\
1(9.1) \\
0(0.0) \\
0(0.0) \\
0(0.0) \\
1(9.1)\end{array}$ & $\begin{array}{r}12(57.1) \\
5(23.8) \\
3(14.3) \\
1(4.8) \\
0(0.0) \\
0(0.0) \\
0(0.0) \\
0(0.0) \\
0(0.0)\end{array}$ & 0.40 \\
\hline $\begin{array}{l}\text { Stanford AD type, } n(\%) \\
\text { N/A } \\
\text { A } \\
\text { B }\end{array}$ & $\begin{aligned} & 2(5.8) \\
& 13(38.2) \\
& 19(53)\end{aligned}$ & $\begin{array}{l}1(9.1) \\
6(54.5) \\
4(36.4)\end{array}$ & $\begin{aligned} & 1(4.8) \\
& 12(57.1) \\
& 8(38.1)\end{aligned}$ & 0.70 \\
\hline $\begin{array}{l}\text { Duration, } n(\%) \\
\text { Transient } \\
\text { Permanent }\end{array}$ & $\begin{array}{r}5(14.7) \\
29(85.3)\end{array}$ & $\begin{array}{c}0(0.0) \\
11(100)\end{array}$ & $\begin{array}{c}2(9.5) \\
19(90.5)\end{array}$ & 0.40 \\
\hline $\begin{array}{l}\text { Pain, } n(\%) \\
\text { Yes } \\
\text { No }\end{array}$ & $\begin{array}{l}19(55.9) \\
15(44.1)\end{array}$ & $\begin{array}{l}5(45.5) \\
6(54.5)\end{array}$ & $\begin{array}{r}8(38.1) \\
13(61.9)\end{array}$ & 0.50 \\
\hline $\begin{array}{l}\text { Pain location, } n(\%) \\
\text { Chest } \\
\text { Back } \\
\text { Chest and back } \\
\text { Chest, back, and abdomen }\end{array}$ & $\begin{array}{l}11(57.89) \\
5(26.3) \\
2(10.5) \\
1(5.2)\end{array}$ & $\begin{array}{l}3(60.0) \\
2(40.0) \\
0(0.0) \\
0(0.0)\end{array}$ & $\begin{array}{l}4(50.0) \\
4(50.0) \\
0(0.0) \\
0(0.0)\end{array}$ & 0.83 \\
\hline $\begin{array}{l}\text { MRI findings, } n(\%) \\
\text { N/A } \\
\text { Normal } \\
\text { Conus } \\
\text { Thoracic } \\
\text { Thoracic and conus } \\
\text { Thoracolumbar } \\
\text { Thoracolumbar and conus }\end{array}$ & $\begin{array}{l}21(61.7) \\
6(17.6) \\
0(0.0) \\
5(14.7) \\
1(2.9) \\
1(2.9) \\
0(0.0)\end{array}$ & $\begin{array}{l}7(63.6) \\
0(0.0) \\
1(9.1) \\
1(9.1) \\
1(9.1) \\
0(0.0) \\
1(9.1)\end{array}$ & $\begin{array}{c}14(66.7) \\
2(9.5) \\
1(4.8) \\
4(19.0) \\
0(0.0) \\
0(0.0) \\
0(0.0)\end{array}$ & 0.34 \\
\hline $\begin{array}{l}\text { Treatment, } n(\%) \\
\text { No treatment } \\
\text { Conservative } \\
\text { CSF drainage } \\
\text { Endovascular } \\
\text { Open surgery }\end{array}$ & $\begin{aligned} & (5.8) \\
12 & (35.3) \\
5 & (14.7) \\
2 & (5.8) \\
13 & (38.2)\end{aligned}$ & $\begin{array}{l}1(9.1) \\
5(45.5) \\
1(9.1) \\
0(0.0) \\
4(36.3)\end{array}$ & $\begin{array}{l}11(52.4) \\
8(38.1) \\
0(0.0) \\
0(0.0) \\
2(9.5)\end{array}$ & $\begin{array}{l}0.96^{1} \\
0.007^{2} \\
0.13^{3}\end{array}$ \\
\hline
\end{tabular}


$2 / 2(100 \%)$ of patients undergone endovascular surgery, 5/6 (83.3) of patients undergone CSF drainage, and $13 / 19$ (68.4\%) undergone surgery versus $12 / 25$ (48\%) of patients received conservative treatment end up walking.

\section{Conclusion}

In our review to cases of $\mathrm{SCI}$ due to $\mathrm{AD}$, we found that it is more common in males above 55 years, pain only found in $47.8 \%$ of patients, with anterior cord syndrome on top of the clinical presentations, whether permanent or transient, and HTN is the most common risk factor. MRI spine could be normal in up to third of cases specially if done early with thoracic location predominance in positive cases. Surgical or endovascular repair especially for type A and complicated type B should be considered to avoid complications, CSF drainage is a very useful tool in reversing spinal cord ischemia, which is setting of AD specially if done early with favorable outcome. Only the old age is associated with increased risk of mortality. Early diagnosis and appropriate management are crucial for better outcome.

\section{Statement of Ethics}

The study was performed in accordance with the Declaration of Helsinki. Written Informed consent to participate was obtained from the patient. The paper is exempt from Ethical Committee Approval as it is a case report not a case study.

Written consent to publish was obtained from study participants for the publication of this case report and any accompanying images.

\section{Conflict of Interest Statement}

The authors declare that they have no competing interests.

\section{Funding Sources}

This work has not received any governmental or nongovernmental funds.

\section{Author Contributions}

H.E. assisted with literature search, data acquisition, and analysis; and prepared and edited the manuscript. A.I.: prepared and edited the manuscript. A.A., M.A., W.A., and S.F. contributed to literature research and prepared the manuscript. All authors have read and approved the manuscript.

\section{Data Availability Statement}

The datasets used and analyzed during the current study are available from the corresponding author on reasonable request.

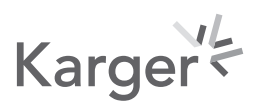




\section{References}

1 Qureshi AI, Afzal MR, Suri MFK. A population-based study of the incidence of acute spinal cord infarction. J Vasc Interv Neurol. 2017;9(4):44-8.

2 Nedeltchev K, Loher TJ, Stepper F, Arnold M, Schroth G, Mattle HP, et al. Long-term outcome of acute spinal cord ischemia syndrome. Stroke. 2004;35(2):560-5.

3 Zalewski NL, Flanagan EP, Keegan BM. Evaluation of idiopathic transverse myelitis revealing specific myelopathy diagnoses. Neurology. 2018;90:e96-102.

4 Rubin MN, Rabinstein AA. Vascular diseases of the spinal cord. Neurol Clin. 2013;31(1):153-81.

5 Pikija S, Mutzenbach JS, Kunz AB, Nardone R, Leis S, Deak I, et al. Delayed hospital presentation and neuroimaging in non-surgical spinal cord infarction. Front Neurol. 2017;8:143.

6 Schneider GS. Anterior spinal cord syndrome after initiation of treatment with atenolol. J Emerg Med. 2010; 38(5):e49-52.

7 Bartnett HJM, Mohr JP, Stein BM, Yatsu FM. Stroke: pathophysiology, diagnosis and management. 4th ed. Philadelphia: Churchill Livingstone; 2004. p. 751-62.

8 Gaul C, Dietrich W, Erbguth FJ. Neurological symptoms in aortic dissection: a challenge for neurologists. Cerebrovasc Dis. 2008;26(1):1-8.

9 Lynch DR, Dawson TM, Raps EC, Galetta SL. Risk factors for the neurologic complications associated with aortic aneurysms. Arch Neurol. 1992;49(3):284-8.

10 Robertson CE, Brown RD, Wijdicks EF, Rabinstein AA. Recovery after spinal cord infarcts: long-term outcome in 115 patients. Neurology. 2012;78(2):114-21.

11 Chase TN, Rosman NP, Price DL. The cerebral syndromes associated with dissecting aneurysms of the aorta: a clinicopathological study. Brain. 1968;9:173-90.

12 Meszaros I, Morocz J, Szlavi J, Schmidt J, Tornóci L, Nagy L, et al. Epidemiology and clinicopathology of aortic dissection. Chest. 2000;117:1271-8.

13 Blanco M, Díez-Tejedor E, Larrea JL, Ramírez U. Neurologic complications of type I aortic dissection. Acta Neurol Scand. 1999;99:232-5.

14 Weisman AD, Adams RD. The neurological complications of dissecting aortic aneurysm. Brain. 1944;67(2): 69-92.

15 Álvarez Sabín J, Vázquez J, Sala A, Ortega A, Codina Puiggrós A. Manifestaciones neurológicas de los aneurismas disecantes de aorta. Med Clin. 1989;92:447-9.

16 Fann JI, Smith JA, Miller DC, Mitchell RS, Moore KA, Grunkemeier G, et al. Surgical management of aortic dissection during a 30-year period. Circulation. 1995;92:II113-21.

17 Sandhu HK, Charlton-Ouw KM, Jeffress K, Leake S, Perlick A, Miller CC, et al. Risk of mortality after resolution of spinal malperfusion in acute dissection. Ann Thorac Surg. 2018;106:473-81.

18 Waltimo O, Karli P. Aortic dissection and paraparesis. Eur Neurol. 1980;19:254-7.

19 Gerber 0, Heyer EJ, Vieux U. Painless dissections of the aorta presenting as acute neurologic syndromes. Stroke. 1986;17:644-7.

20 Rosen SA. Painless aortic dissection presenting as spinal cord ischemia. Ann Emerg Med. 1988;17:840-2.

21 Zull DN, Cydulka R. Acute paraplegia: a presenting manifestation ofaortic dissection. Am J Med. 1988;84:76570.

22 Tanaka T, Uemura K, Sugiura M, Ohishi H, Tomita M, Nagasaki F, et al. Transient paraplegia caused by acute aortic dissection: case report. Neurol Med Chir. 1990;30:54-8.

23 Holloway SF, Fayad PB, Kalb RG, Guarnaccia JB, Waxman SG. Painless aortic dissection presenting as a progressive myelopathy. J Neurol Sci. 1993;120:141-4. 120

24 Krishnamurthy P, Chandrasekaran K, Rodriguez Vega JR, Grunewald K. Acute thoracic aortic occlusion resulting from complex aortic dissection and presenting as paraplegia. J Thorac Imaging. 1994;9(2):101-4.

25 Kellett MW, Young GR, Fletcher NA. Paraparesis due to syphilitic aortic dissection. Neurology. 1997;48(1): 221-3.

26 Beach C, Manthey D. Painless acute aortic dissection presenting as left lower extremity numbness. Am J Emerg Med. 1998;16:49-51.

27 Lacerda RC, Andrea PB, Machado Neto E, de Figueiredo CB, Teixeira AB, de Carvalho PC. Acute paraplegia. A rare complication of aortic dissection. Arq Bras Cardiol. 1998;70:275-8.

28 Donovan EM, Seidel GK, Cohen A. Painless aortic dissection presenting as high paraplegia: a case report. Arch Phys Med Rehabil. 2000;81(10):1436-8.

29 Joo JB, Cummings AJ. Acute thoracoabdominal aortic dissection presenting as painless, transient paralysis of the lower extremities: a case report. J Emerg Med. 2000;19(4):333-7.

30 Inamasu J, Hori S, Yokoyama M, Funabiki T, Aoki K, Aikawa N. Paraplegia caused by painless acute aortic dissection. Spinal Cord. 2000;38:702-4.

31 Killen DA, Weinstein CL, Reed WA. Reversal of spinal cord ischemia resulting from aortic dissection. J Thorac Cardiovasc Surg. 2000;119(5):1049-52.

32 Syed MA, Fiad TM. Transient paraplegia as a presenting feature of aortic dissection in a young man. Emerg Med J. 2002;19(2):174-5.

33 Patel NM, Noel CR, Weiner BK. Aortic dissection presenting as an acute cauda equina syndrome: a case report. J Bone Joint Surg Am. 2002 Aug;84(8):1430-2. 
34 Ohmi M, Shibuya T, Kawamoto S, Shimizu M, Nakame T, Kurihara N. [Spinal cord ischemia complicated with acute aortic dissection and intramural hematoma; report of two cases]. Kyobu Geka. 2003;56:473-8.

35 Blacker DJ, Wijdicks EF, Ramakrishna G. Resolution of severe paraplegia due to aortic dissection after CSF drainage. Neurology. 2003;61:142-3.

36 Ogun SA, Adefuye B, Kolapo KB, Osalusi BS. Anterior spinal artery syndrome complicating aortic dissecting aneurysm: case report. East Afr Med J. 2004;81:549-52.

37 Hsu YC, Lin CC. Paraparesis as the major initial presentation of aortic dissection: report of 4 cases. Acta Neurol Taiwan. 2004;13(4):192-7.

38 Chiang JK, Tsai KW, Lin CW, Shen TC, Hu SC, Chen CY. Acute paraplegia as the presentation of aortic dissection: a case report. Tzu Chi Med J. 2005;17(5):369-71.

39 Fujisawa Y, Morishita K, Fukada J, Kawaharada N, Hachiro Y, Abe T. Treatment methods for spinal cord injury caused by acute type B aortic dissection. Asian Cardiovasc Thorac Ann. 2006 Dec;14(6):e106-7.

40 Altuwaijri M, Delis KT, Vrtiska T, Fulgham JR, Gloviczki P. Aortic fenestration for chronic aortic dissection type B complicated by transient ischemic attacks of spinal cord. J Vasc Surg. 2006;44(1):186-93.

41 Aktas C, Cinar O, Ay D, Gürses B, Hasmanoglu H. Acute aortic dissection with painless paraplegia: report of 2 cases. Am J Emerg Med. 2008;26(5):631.e3-5.

42 Hölper P, Hyhlik-Dürr A, Kotelis D, von Tengg-Kobligk H, Böckler D. Paraplegia after spontaneous dissection of the abdominal aorta. Vasa. 2009 Aug;38(3):254-8.

43 Karacostas D, Anthomelides G, Ioannides P, Psaroulis K, Psaroulis D. Acute paraplegia in painless aortic dissection. Rich imaging with poor outcome. Spinal Cord. 2010;48(1):87-9.

44 TaHsieh C, Chung T, Liu M. Monoplegia and paresthesia as rare presentations of type B aortic dissection. Tzu Chi Med J. 2011;23(4):142-4.

45 Zeggeren L, Waasdorp EJ, de Worp B, Meijer ST, Moll FL, Borst G. Painless transient paraparesis as the solitary manifestation of aortic dissection. J Vasc Surg. 2011;54(5):1481-4.

46 Hayatsu Y, Nagaya K, Sakuma K, Nagamine S. A case of effective cerebrospinal fluid drainage for paraplegia caused by acute aortic dissection. Ann Vasc Dis. 2011;4(1):64-6.

47 Sui R-B, Zhang L, Liu K. Aortic dissection presenting primarily as acute spinal cord damage: a case report and literature review. J Int Med Res. 2012;40(5):2014-20.

48 Colak N, Nazli Y, Alpay MF, Akkaya IO, Cakir O. Painless aortic dissection presenting as paraplegia. Tex Heart Inst J. 2012;39(2):273-6.

49 Lynch K, Oster J, Apetauerova D, Hreib K. Spinal cord stroke: acute imaging and intervention. Case Rep Neurol Med. 2012;2012:706780.

50 Tsiouris A, Morgan JA, Paone G. Type A aortic dissection presenting with isolated paraplegia. Heart Surg Forum. 01 Dec 2012;15(6):E316-7.

51 Hui C, Lau P. Aortic dissection presented as paraparesis: a case report with literature review. Hong Kong ] Emerg Med. 2013;20(5):312-6.

52 Rabadi MH. Acute aortic dissection presenting as painless paraplegia. J Gen Intern Med. 2014 Feb;29(2):410-1.

53 Ullery BW, Hobbs RD, Cheung AT. Reversible spinal cord ischemia as a complication of acute aortic intramural hematoma. Vascular. 2015 Aug;23(4):427-31.

54 He F, Xing T, Yu F, Li H, Fang X, Song H. Cauda equina syndrome: an uncommon symptom of aortic diseases. Int J Clin Exp Med. 2015;8(7):10760-6.

55 Yu L, Gu T, Shi E, Fang Q. Sudden-onset paraplegia and ischemia of the lower extremities from acute aortic occlusion following type A acute dissection. Overview data. Cardiol Pharmacol. 2015;S1:004.

56 Almenara Escribano MD, Jódar Morente FJ, Ortega Armenteros MDC. Dissecting aortic aneurysm presenting as transient spinal cord ischaemia: a case report and literature review. Neurologia. 2018;33:339.

57 Hdiji O, Bouzidi N, Damak M, Mhiri C. Acute aortic dissection presenting as painless paraplegia: a case report. J Med Case Rep. 2016;10:99.

58 Hughes KE, Seguin C, Felton B, Hughes MJ, Castle D. Acute aortic dissection presenting as bilateral lower extremity paralysis: a case report. J Emerg Med. 2016;51(4):450-3.

59 Martínez GG, Ravelo DR, Valdés CE, Cruz RLO, Cárdenas FY, García BCR. Chest pain and paraplegia as a presentation of aortic dissection: apropos of a case. CorSalud. 2016;8(2):127-31.

60 Prakash B, Pai RK, Chaitra V, Ramasamy P, Shuba N. A case of acute paraplegia due to aortic dissection in Marfan syndrome. J Neurosci Rural Pract. 2017;8(2):316-9.

61 Yıldız OK, Dönmez R, Bolayır A, Gökçe SF, Ciğdem B, Balaban H, et al. Aortic dissection presenting with transient paraplegia. Turk J Neurol. 2017;23:239-40.

62 Sekine Y, Nishina T, Ueda Y. Rare spinal cord infarction in a patient with acute type B aortic dissection. Interact Cardiovasc Thorac Surg. 2017;24(6):976-7.

63 Niclauss L, Delay D, von Segesser LK. Recovery of paraplegia after type B dissection due to spinal collateral recruitment. J Vasc Surg. 2012 Jul;56(1):205-7.

64 Cheng K, Perenyei M, Sayeed R. Anterior spinal artery syndrome from type A aortic dissection in a patient with Marfan syndrome due to a novel fibrillin mutation. J R Coll Physicians Edinb. 2018;48:120-3.

65 Kawabata A, Tomori M, Arai Y. Spinal cord infarction with aortic dissection. Case Rep Orthop. 2018;2018: 7042829.

66 Strohm TA, John S, Hussain MS. Cerebrospinal fluid drainage and blood pressure elevation to treat acute spinal cord infarct. Surg Neurol Int. 2018;9:195. 
67 Tsushima T, Al-Kindi S, Patel T, Kalra A. Atypical complications of aortic intramural hematoma: paraplegia resulting from spinal cord infarction. Int J Cardiol Heart Vasc. 2019;22:154-5.

68 Martínez-Quintana E, Gil-Guillén C, Rodríguez-González F. Anterior spinal artery syndrome and aortic dissection. Cir Cir. 2019;87(4):466-9.

69 Memon W, Aijaz Z, Memon R. Paraplegia and acute aortic dissection: a diagnostic challenge for physicians in the emergency situation. BMJ Case Rep. 2019 Jul 8;12(7):e230561.

70 Takeda S, Tanaka Y, Sawada Y, Tabuchi A, Hirata H, Mizumoto T. Repetitive transient paraplegia caused by painless acute aortic dissection. Acute Med Surg. 2019;6(2):188-91.

71 Sabugueiro J, Olson S. Type A aortic dissection in a patient with suspected cauda equina syndrome: a masquerader. BIR Annual Conference. Eposter; 2019.

72 Kim H, Heo W, Song SW, Yoo KJ. Case report: left monoplegia in acute type B aortic dissection. AME Case Rep. 2020;4:16.

73 Nahed RA, Rizk W. A transient spinal cord ischemia reveals a silent type A aortic dissection. JNSK. 2021;11(1):20.

74 Hagan PG, Nienaber CA, Isselbacher EM, Bruckman D, Karavite DJ, Russman PL, et al. The international registry of acute aortic dissection: new insights into an old disease. JAMA. 2000;283:897-903.

75 Etgen T, Langer R, Neff F, Sander K, Conrad B, Sander D. Dopplersonographie mit hinweis auf fulminante aortendissektion bei initialem mediainfarkt. Nervenarzt. 2005;76(8):976-9.

76 Fessler AJ, Alberts MJ. Stroke treatment with tissue plasminogen activator in the setting of aortic dissection. Neurology. 2000;54:1010.

77 Flemming KD, Brown RD. Acute cerebral infarction caused by aortic dissection: caution in the thrombolytic era. Stroke. 1999;30:477-8.

78 Stanley I, Sharma VK, Tsivgoulis G, Lao AY, Alexandrov AV. Painless aortic dissection with unusual extension into intracranial internal carotid arteries. Cerebrovasc Dis. 2007;24:314-5.

79 Ibaraki T, Fukumoto H, Nishimoto Y, Nishimoto M, Suzuki S, Morita H. [Surgical management of acute type A aortic dissection with a complaint of disturbance of consciousness; report of a case]. Kyobu Geka. 2002;55: 1053-6.

80 Morita S, Shibata M, Nakagawa Y, Yamamoto I, Inokuchi S. Painless acute aortic dissection with a left hemiparesis. Neurocrit Care. 2006;4:234-6.

81 Wright V, Horvath R, Baird AE. Aortic dissection presenting as acute ischemic stroke. Neurology. 2003;61: $581-2$.

82 Khan IA, Nair CK. Clinical, diagnostic, and management perspectives of aortic dissection. Chest. 2002;122: 311-28.

83 Beggs AD, Al-Rawi H, Parfitt A. Chest pain and fleeting neurological signs. Lancet. 2005;365:1514.

84 Grassner L, Klausner F, Wagner M, McCoy M, Golaszewski S, Leis S, et al. Acute and chronic evolution of MRI findings in a case of posterior spinal cord ischemia. Spinal Cord. 2014 Jun;52(Suppl 1):S23-4.

85 Sakurai T, Wakida K, Nishida H. Cervical posterior spinal artery syndrome: a case report and literature review. J Stroke Cerebrovasc Dis. 2016;25(6):1552-6.

86 Struhal W, Seifert-Held T, Lahrmann H, Fazekas F, Grisold W. Clinical core symptoms of posterior spinal artery ischemia. Eur Neurol. 2011;65(4):183-6.

87 Zalewski NL, Rabinstein AA, Wijdicks EFM, Petty GW, Pittock SJ, Mantyh WG, et al. Spontaneous posterior spinal artery infarction: an underrecognized cause of acute myelopathy. Neurology. 2018;91(9):414-7.

88 Novy J, Carruzzo A, Maeder P, Bogousslavsky J. Spinal cord ischemia: clinical and imaging patterns, pathogenesis, and outcomes in 27 patients. Arch Neurol. 2006;63(8):1113-20.

89 Weidauer S, Nichtweiss M, Lanfermann H, Zanella FE. Spinal cord infarction: MR imaging and clinical features in 16 cases. Neuroradiology. 2002;44(10):851-7.

90 Foo D, Rossier AB. Anterior spinal artery syndrome and its natural history. Paraplegia. 1983;21(1):1-10.

91 Hsu JL, Cheng MY, Liao MF, Hsu HC, Weng YC, Chang KH, et al. The etiologies and prognosis associated with spinal cord infarction. Ann Clin Transl Neurol. 2019;6(8):1456-64.

92 Tsai TT, Nienaber CA, Eagle KA. Acute aortic syndromes. Circulation. 2005;112:3802-13.

93 Vargas MI, Gariani J, Sztajzel R, Barnaure-Nachbar I, Delattre BM, Lovblad KO, et al. Spinal cord ischemia: practical imaging tips, pearls, and pitfalls. AJNR Am J Neuroradiol. 2015;36(5):825-30.

94 DeBakey ME, Henly WS, Cooley DA, Morris GC Jr, Crawford ES, Beall AC Jr. Surgical management of dissecting aneurysms of the aorta. J Thorac Cardiovasc Surg. 1965;49:130-49.

95 Daily PO, Trueblood HW, Stinson EB, Wuerflein RD, Shumway NE. Management of acute aortic dissections. Ann Thorac Surg. 1970;10(3):237-47.

96 Howard DP, Sideso E, Handa A, Rothwell PM. Incidence, risk factors, outcome and projected future burden of acute aortic dissection. Ann Cardiothorac Surg. 2014;3(3):278-84.

97 Nienaber CA, Powell JT. Management of acute aortic syndromes. Eur Heart J. 2012;33:26-35b.

98 Suzuki T, Isselbacher EM, Nienaber CA, Pyeritz RE, Eagle KA, Tsai TT, et al. Type-selective benefits of medications in treatment of acute aortic dissection (from the International Registry of Acute Aortic Dissection [IRAD]). Am J Cardiol. 2012;109(1):122-7.

99 Lu Q, Feng J, Zhou J, Zhao Z, Bao J, Feng R, et al. Endovascular repair of ascending aortic dissection: a novel treatment option for patients judged unfit for direct surgical repair. J Am Coll Cardiol. 2013;61:1917-24.

100 Erbel R, Aboyans V, Boileau C, Bossone E, Bartolomeo RD, Eggebrecht H, et al. The task force for the diagnosis and treatment of aortic diseases of the European Society of Cardiology (ESC). Eur Heart J. 2014;35:2873-926. 
101 Grabenwoger M, Alfonso F, Bachet J, Bonser R, Czerny M, Eggebrecht H, et al. Thoracic endovascular aortic repair (TEVAR) for the treatment of aortic diseases: a position statement from the European Association for Cardio-Thoracic Surgery (EACTS) and the European Society of Cardiology (ESC), in collaboration with the European Association of Percutaneous Cardiovascular Interventions (EAPCI). Eur Heart J. 2012;33:1558-63.

102 Cinà CS, Abouzahr L, Arena GO, Laganà A, Devereaux PJ, Farrokhyar F. Cerebrospinal fluid drainage to prevent paraplegia during thoracic and thoracoabdominal aortic aneurysm surgery: a systematic review and metaanalysis. J Vasc Surg. 2004;40:36-44.

103 Coselli JS, LeMaire SA, Köksoy C, Schmittling ZC, Curling PE. Cerebrospinal fluid drainage reduces paraplegia after thoracoabdominal aortic aneurysm repair: results of a randomized clinical trial. J Vasc Surg. 2002;35: 631-9.

104 Martirosyan NL, Kalani MY, Bichard WD, Baaj AA, Gonzalez LF, Preul MC, et al. Cerebrospinal fluid drainage and induced hypertension improve spinal cord perfusion after acute spinal cord injury in pigs. Neurosurgery. 2015;76:461-9.

105 Svensson LG, Hess KR, D’Agostino RS, Entrup MH, Hreib K, Kimmel WA, et al. Reduction of neurologic injury after high-risk thoracoabdominal aortic operation. Ann Thorac Surg. 1998;66(1):132-8.

106 Trabattoni P, Zoli S, Dainese L, Spirito R, Biglioli P, Agrifoglio M. Aortic dissection complicating intraaortic balloon pumping: percutaneous management of delayed spinal cord ischemia. Ann Thorac Surg. 2009;88(6): e60-2.

107 Azizzadeh A, Huynh TT, Miller CC, Safi HJ. Reversal of twice-delayed neurologic deficits with cerebrospinal fluid drainage after thoracoabdominal aneurysm repair: a case report and plea for a national database collection. J Vasc Surg. 2000;31(3):592-8.

108 Crawford ES, Svensson LG, Hess KR, Shenaq SS, Coselli JS, Safi HJ, et al. A prospective randomized study of cerebrospinal fluid drainage to prevent paraplegia after high-risk surgery on the thoracoabdominal aorta. J Vasc Surg. 1991;13(1):36-6.

109 Salvador de la Barrera S, Barca-Buyo A, Montoto-Marqués A, Ferreiro-Velasco ME, Cidoncha-Dans M, Rodriguez-Sotillo A. Spinal cord infarction: prognosis and recovery in a series of 36 patients. Spinal Cord. 2001;39(10):520-5.

110 Masson C, Pruvo JP, Meder JF, Cordonnier C, Touzé E, De La Sayette V, et al. Spinal cord infarction: clinical and magnetic resonance imaging findings and short term outcome. J Neurol Neurosurg Psychiatry. 2004;75(10): 1431-5.

111 Robertson CE, Brown RD, Wijdicks EF, Rabinstein AA. Recovery after spinal cord infarcts: long-term outcome in 115 patients. Neurology. 2012;78(2):114-21.

112 Spittell PC, Spittell JA Jr, Joyce JW, Tajik AJ, Edwards WD, Schaff HV, et al. Clinical features and differential diagnosis of aortic dissection: experience with 236 cases (1980 through 1990). Mayo Clin Proc. 1993;68:642-51. 